\title{
MOTIVATIONAL FACTORS AFFECTING RETENTION IN PRE-SERVICE TEACHER EDUCATION ACROSS KARACHI, PAKISTAN
}

\author{
Intizar Hussain \\ Research Scholar, \\ Department of Education, University of Karachi, \\ Sindh, Pakistan \\ Email: intizar@uok.edu.pk

\section{Hina Hussain Kazmi} \\ CEO, \\ TAF Foundation, Karachi \\ Sindh, Pakistan \\ Email: hinakazmi1@hotmail.com
}

\begin{abstract}
The undertaken study is intended to investigate motivations of student-teachers in the teaching profession. The sampled respondents include trainee prospective-teachers enrolled in B Ed Honors programs offered by University of Karachi through its affiliated colleges and at its main campus. This study ascertains the Factors that Contribute to their Motivation for Joining teaching profession. Obtained data was analyzed using ANOVA and T-Test statistics. Inferential statistics enabled researchers to find hidden meanings of the data by examining the difference between means of the data; by establishing relationships between the Variables of interest. some interesting findings such as; social utility of teaching, gender influence on selecting profession of teaching, parental qualification and profession's influence on prospective teachers' motivation etc. were challenging the traditionally held myths about motivational factors in choosing teaching profession, . The study bears implications for different stakeholders of the teacher education system in order to develop a learning environment that motivates the students to perform and achieve well.
\end{abstract}

\section{KEYWORDS}

Motivational Factors, Teaching Profession, Teacher Education, Career in Teaching, Teacher Retention, Prospective Teachers

\section{INTRODUCTION}

Sinclair et al. (2008) argues that students are more engaged and interested in their training if they enter pre-service programs with the "right" motives and that students 
with the "right" motives are more committed to teaching as a profession and are likely to remain in the profession. Those who enter teaching for the "wrong" reasons - such as those who joined a program because they could not choose the majors of their choice-leave teaching sooner than the former group. Yet, the institution of teacher training, even in more developed countries, cannot select pre-service teachers on the basis of their motivation to become a teacher. Sinclair et al. (2008) argues that nature of motives plays significant role in performing good or bad in teaching profession. $\mathrm{He}$ says those who entered with good motives they enjoy, learn perform and deliver to the masses but those who entered with substandard motives. They, feel difficulty, unable to learn, unable to perform, don't enjoy, unable to perform, unable to deliver students and become anxious. So the institution should select candidate for teacher education on the basis of their motives. Unfortunately institution for teachers professional development are not selecting on the basis of their motivation in even in developed countries

In this context the present study was proposed to understand the motivation of prospective teachers towards the profession of teaching. Several studies done in various countries show that understanding teachers' motivation for choosing to teach is critical in understanding how prospective quality teachers can be attracted and retained (Sinclair et al. 2008; Watt and Richardson 2007). This study aims to identify the factors of motivation of pre-service teachers to become a teacher as related to their background characteristics such as gender, parental qualification, ethnicity and other demographics.

\section{LITERATURE REVIEW}

Teacher Education has failed to attract academically sound students across the globe. Despite teaching being regarded as a highly respectable profession, students are reluctant to join this profession because of low quality of training programs, lack of incentives, low social value, and low wages (Fazal-ur-Rehman, 2005). Moreover, subordinate status, and limited career opportunities for the school teachers have also contributed in de-motivating academically competent students from joining teacher education (Malloy \&Wohlstetter, 2003). Students' motivation is a widely discussed and debated area because its affecting factors are being continuously changed. Motivation commonly refers to an internal state that arouses, directs and sustains human behavior which leads to outlay of effort to accomplish results (DuBrin, 2008). This urge in an individual leads to actions like enrolling in a course of teachereducation etc. (Sinclair, 2008). It also involves energy and drive to learn, work effectively, and achieve potential. Motivation contributes significantly in the interest and enjoyment of study (Martin, 2003).

For imparting the teacher-education motivation play a significant role in attracting 
individuals for adopting and performing teaching profession, in bringing them in teacher-education department to gain higher professional qualification, in completing their professional qualification, in retaining them in the teaching profession as well as in encouraging them to concentrate on their learning and on their practices (Sinclair, 2008). It can be said that motivation determine three kinds of activities, namely attraction, retention, and concentration. Numerous cross-disciplinary theories have been postulated to explain motivation. The most popularly followed notions are intrinsic and extrinsic motivation. Some theories claim extrinsic motivation works more while other believes in intrinsic motivation, first one is worked on external rewards while other one moves on internal feelings and desires. Numerous researchers conclude that intrinsic motivation is the sole sustained inspiration for prospective teachers to join the teaching profession. The researches have put forward ample evidence to show that intrinsically motivated persons are productive, proud, and happy and contribute to show their competence and achievements (Smith, 2010).

Besides recognizing the significance of these two aspects of motivation, bigger part of literature signifies that a large amount of researches are related to intrinsic motivation instead of extrinsic motivation . Extrinsic and intrinsic motivation is interdependent as well therefore it is equally desirable to address both in order to attract and retain student teachers towards teaching. A teacher who is intrinsically motivated definitely will be extrinsically motivated too (Bruinsma\& Jansen, 2010). Stembridge (1989) and Bostwick (2010) indicated that intrinsic motivation is one influential factor of choosing teaching as a career while Martin (2010) said extrinsic motivation also influences prospective teachers to learn during teacher education. So this indicates that both extrinsic and intrinsic motivations are not opposite or rivals to each other but two dimensions in which teacher educators fluctuate themselves depending on the situations (Bruinsma\& Jansen, 2010). Although literature is abundant on vitality of both intrinsic and extrinsic motivation behind prospective teachers joining the teaching profession but it is inconclusive on extrinsic motivation leading to intrinsic motivation or vice versa (Richardson \& Watt, 2007). There is ample evidence leading that motivation can be enhanced/changed through various means. This brings to a close that motivation can be fostered and retained during the teacher-education program (Smith, 2010).

\section{Factors Leading to Choose Teaching as Profession}

Although the reasons for joining the teaching profession can be broadly categorized into internal and external motivational factors, different individuals have different reasons for becoming a teacher. Edmonds, Sharp and Benefield (2002) suggested that every individual's motivational factors are different because of his or her profile. Findings of the research reported $81 \%$ intrinsic and $19 \%$ extrinsic motivations get the students to enroll in teacher education programs (ÜSTÜNER, DEMIRTAŞ \& 
CÖMERT , 2009). Participants' goal of becoming teachers were influenced four main sources. These were family, teacher, peer, and teaching-experiences

\section{Prioritization of Teaching as a Profession}

In late 90s a survey was conducted that explored that around 87 percent of students took teaching as the most respectable profession, while only 42 percent chose it as their first choice. Most of the teachers seemed annoyed with teaching profession and they did not intend to make their children teacher. They also avoided to encourage their students to be a teacher. Kudos (1997) identified that Two-thirds of parents had intention to encourage their children to adopt teaching as profession that there children but none recorded teaching as their preferred choice of profession for their children.

\section{Measuring Motivation: Theoretical Framework}

There are as many tools as researchers interested in measuring motivation. The choice of instrument becomes very difficult as most of the instruments apparently look relevant but have contextual variations which make them irrelevant. There are instruments which are not based on any theory apparently and are not even used by any researchers other than who developed them. It is quite difficult to find instruments which are used in more than one study and across various countries of the world to trust the ecological validity.

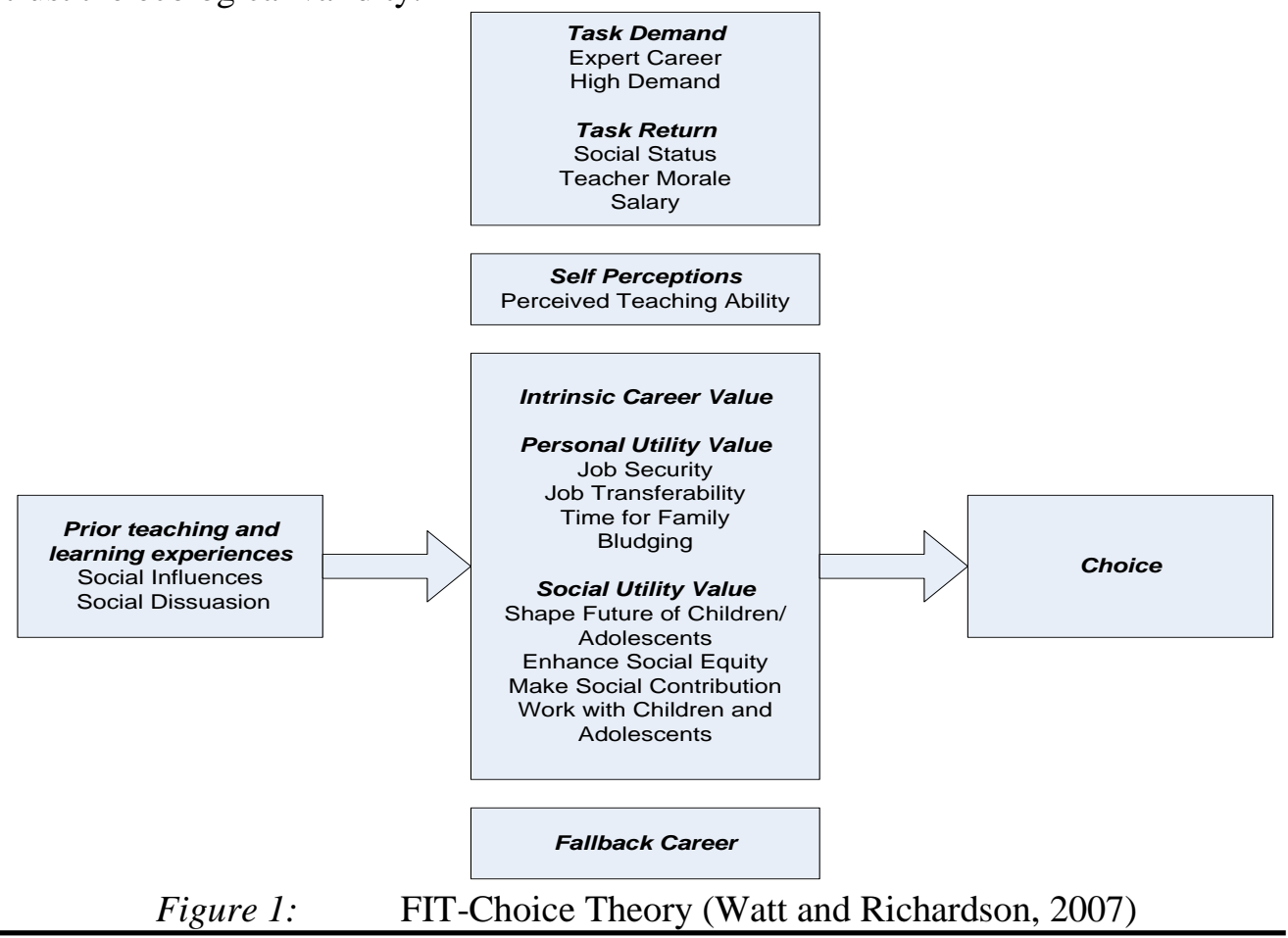


Watt and Richardson, (2007) developed Fit Choice Scale to determine various factors influences an individual's choice of career. Several studies have replicated this scale to investigate such factors in their own context. Its constituent's i.e. personal beliefs, personal utility values and social utility values embrace elements of motivation already explored in the literature. The three value scales, though developed in Australia, have relevance in Pakistani cultural context of considering teaching as a respectful profession.

Several studies have been carried out that survey pre-service teachers and categorize their motivations into these three categories (Brookhart \& Freeman, 1992; Rena \& Suleman, 2010; Witcher et al., 2008). However, a criticism of these researches is that they are a-theoretical: that is, they are not based on any existing theory of motivation.

Richardson and Watt's (2006), model called the Factors Influencing Teaching Choice (FIT-Choice) theory is to date the most comprehensive model to study motivation that is based on the Expectancy Value Theory of Motivation ${ }^{[1]}$ and has been used extensively in similar studies (see, for example, Eren \& Tezel, 2010; Mtika \& Gates, 2010; Roness \& Smith, 2010; Smith \& Pantana, 2010; Watt \& Richardson, 2007). The model is shown graphically in figure 1 .

\section{RESEARCH QUESTION}

How is the motivation of prospective teachers related with their retention in teaching on the Personal Utility Values Scale?

\section{Subsidiary Questions}

1. How does job security factor affect the motivation of pre service teachers for joining teaching as a profession?

2. How does job transferability affect the motivation of pre service teachers for joining teaching as a profession?

3. How does time for family factor affect the motivation of pre service teachers for joining teaching as a profession?

5. How does bludging (to avoid work and responsibility) factor affect the motivation of pre service teachers for joining teaching as a profession??

\section{RESEARCH METHODOLOGY}

The sample of this study consisted those ADE and B. Ed (Honors) prospective teachers from the institutions in Karachi which have launched the said program more than a period of four years from 2019, and at least the respondent prospective teachers have reached semester three at the time of data collection i.e. January 2020. So all of the prospective teachers enrolled in University of Karachi at their campuses and at 04 affiliated colleges in Karachi were included in the study. These four colleges were; 
Government College of Education F B Area Karachi, GECET Hussainabad Karachi, GECET Qasimabad Karachi and GECET Lyari Karachi.

\section{Data Collection Instrument}

Researcher adapted FIT choice scale to investigate the relationship of the variable of interest. He translated the scale in to Urdu in remove any sort of hindrances of comprehension as well as to increase the sphere of respondents as prospective teacher from any background or nay subject was included. This translated instrument was named APTSTP-scale (Attitude of Prospective Teachers for Selecting Teaching Profession). The scale consists of three sub scales; Motivational Belief Scale, Personal Utility Value Scale and Social Utility Scale. Each subscale consisted of 24, 13 and 6 items respectively. The range of the scale is $1-5$ where 1 means extremely unimportant and 5 means extremely important while 3 means neutral attitude towards the Motivation for Teaching as a profession.

This study was done for the Doctoral Program in Education as per program requirements. The findings generated from one of the three sub-sets contained in Fit Choice Scale 2007 have been reported i.e. Personal Utility Values Scale.

\section{Data Analysis}

\section{Motivational Value of Joining Teacher Education}

Personal Utility Value Scale consisted of 13 items encompassing factors related to job security, job transferability, time for family and bludging (to avoid work or responsibility). The range of the scale is $1-5$ where 1 represents extremely unimportant and 5 represents extremely important while 3 represents neutral attitude towards the Motivation for Teaching as a profession. Descriptive statistics, various tests; ANOVA and T-Test are used to test the difference between means of the obtained data.

\section{FINDINGS}

\section{Personal Utility of teaching for different genders.}

Table 1: Difference in motivation of prospective teachers to join teaching profession by gender

\begin{tabular}{llllllll}
\hline $\begin{array}{l}\text { Type of } \\
\text { Motivation }\end{array}$ & Gender & $\mathrm{N}$ & Mean & $\mathrm{SD}$ & $\mathrm{T}$ & $\mathrm{df}$ & $\mathrm{Sig}$. \\
\hline $\begin{array}{l}\text { Personal Utility } \\
\begin{array}{l}\text { Value Scale } \\
\text { (range 13-65) }\end{array}\end{array}$ & Male & 70 & 54.65 & 1.885 & -2.699 & 258 & .02 \\
\hline
\end{tabular}

In Table 1, researcher presents perception of Prospective teachers of different gender, analyzed through t-test statistics explains the results of Personal Utility Value Scale. 
On the Personal Utility Value Scale, Table 1 shows that Prospective teachers perceive joining the teaching profession of more importance. A little bit difference between male and female PTs' perceptions is found. Mean 51.08 the is the obtained mean of Female PTs on this sub-scale, however 54.65 is the obtained mean of male PTs. Pvalue is. .02 which is smaller than .05 that shows obtained findings are significant.

It is found that male PTs are intrinsically less motivated than the female ones in joining the teaching profession. The other motivational factors have equal influence on the male and female PTs' attitude.

\section{Mother-tongue}

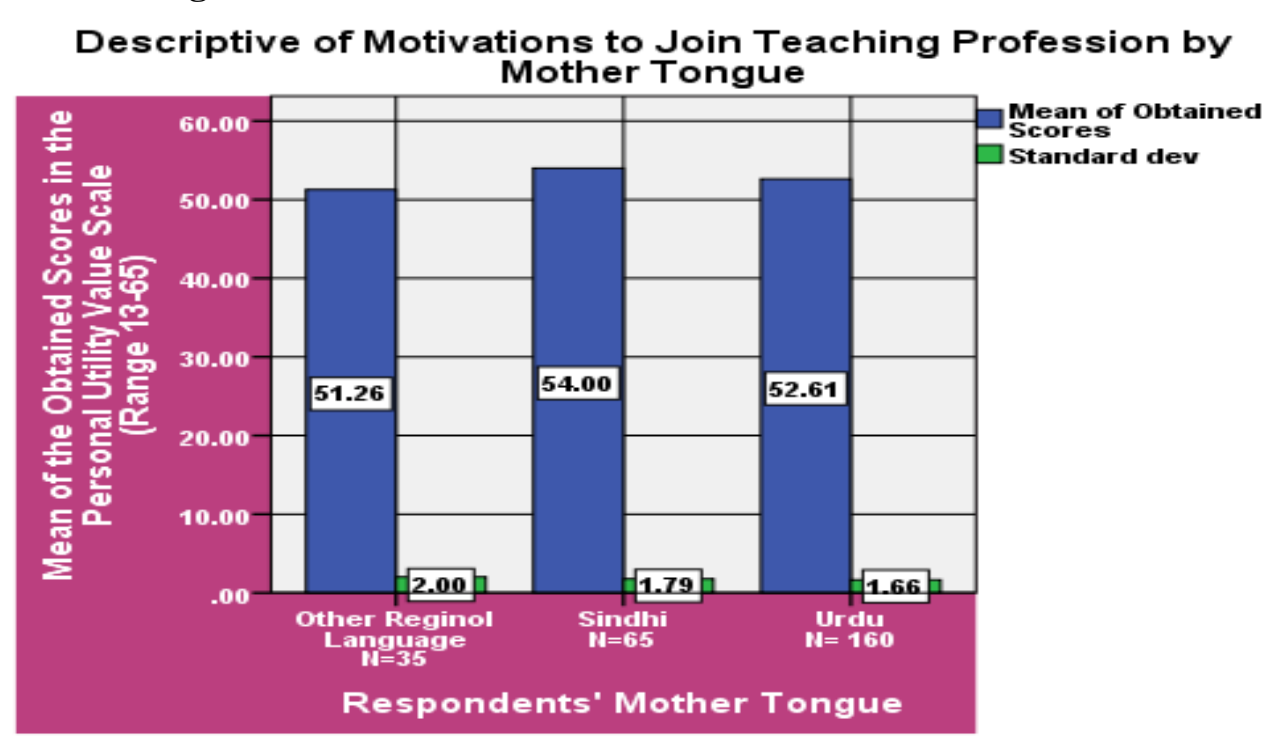

Figure 2: Descriptive of motivations to join teaching profession by mother tongue

Figure 2 represents descriptive statistics graphically that the reader may understand the consistency and deviations of the different sub-groups-made on the basis of Respondents' first language; "Urdu" "Sindhi" and "other than these two languages" on the three subscales: Social Utility Value Scale, Personal Utility Value Scale, Motivational Belief scale.

On the Personal Utility Value Scale the mean of each sub-group found consistent and very close to the population mean. The Standard deviation shows that their opinions about the Personal Utility Value of the teaching profession are not much different as the value of Standard deviation is around 2. 
The observed fact is that the Prospective teachers from Sindhi speaking community are found more motivated intrinsically in joining the teaching profession than the other sub-groups.

\section{Language and choice of teaching profession}

Researchers found the respondents divided into three sub-groups: respondents who have Urdu their first language, who have Sindhi their first language, and who have any regional language other than Urdu and Sindh

Table 2: Descriptive of motivations to join teaching profession by mother tongue

\begin{tabular}{|c|c|c|c|c|c|c|c|c|c|}
\hline \multicolumn{4}{|c|}{ Mother } & \multicolumn{6}{|c|}{$95 \%$ Confidence } \\
\hline \multirow{3}{*}{ S\# } & Tongue & $\mathrm{N}$ & Mopn & Std. & Std. & Interval $\mathrm{f}$ & or Mean & & Movimum \\
\hline & & $\mathbf{N}$ & Mean & Deviation & Error & Lower & Upper & Minımum & Maxımum \\
\hline & & & & & & Bound & Bound & & \\
\hline 1 & ORL & 35 & 51.26 & 2.00 & 1.47871 & 43.5365 & 57.4635 & 48.00 & 51.00 \\
\hline 2 & S & 65 & 54.00 & 1.79 & .94523 & 46.6675 & 60.4635 & 53.00 & 54.00 \\
\hline 3 & $\mathrm{U}$ & 160 & 52.61 & 1.66 & .94521 & 44.7265 & 58.7735 & 51.00 & 52.00 \\
\hline
\end{tabular}

Table 2 describes that respondents who have Urdu their first language obtained 52.61 as a means of obtained scores. Small standard deviation 1.66 in the next column shows that they are consistent in responding. Standard error is also smaller enough that maintains the credibility of the obtained data. Lower boundary and upper boundary of the interval enhance the researcher's confidence about authenticity of the data. minimum and maximum expose the data range. Descriptive of the data portray a picture that shows respondents consistent behavior about the teaching profession. The table shows that the Prospective teachers from Sindhi speaking community obtained higher mean 54 among the all sub groups that explore that they are more motivated intrinsically in joining the teaching profession than the other sub-groups.

Table 3: Comparison of prospective teachers' motivation to join teaching profession by their mother tongue

\begin{tabular}{|l|l|c|c|c|c|c|}
\hline & & $\begin{array}{c}\text { Sum of } \\
\text { Squares }\end{array}$ & df & $\begin{array}{c}\text { Mean } \\
\text { Square }\end{array}$ & F & Sig. \\
\hline $\begin{array}{l}\text { Personal } \\
\begin{array}{l}\text { Utility Value } \\
\text { Scale (range } \\
13-65)\end{array}\end{array}$ & $\begin{array}{l}\text { Between } \\
\text { Groups }\end{array}$ & 19.603 & 2 & 9.802 & .81 & .02 \\
\cline { 2 - 7 } & $\begin{array}{l}\text { Within } \\
\text { Groups }\end{array}$ & 28684.559 & 258 & 121.032 & & \\
\cline { 2 - 7 } & Total & 28704.163 & 260 & & & \\
\hline
\end{tabular}


Table 3 presents the results of impact of first language on the perceptions of Prospective teachers about joining the teaching profession analyzed using F- statistics explains the results of the Personal Utility Value Scale.

In the personal utility value scale, Table 3 presents a difference between groups that is smaller than difference within the group that decreases the F- ratio that is 0.81 that is near to 1 . That shows that alternative hypotheses have been rejected in favor of null hypothesis the PTs perceptions of Personal Utility for joining the teaching profession are not affected by their first language. They are found similar in their perception. The $\mathrm{P}$-value in the table is .02 which is smaller than .05 that shows obtained findings are significant enough.

\section{Mother's Education}

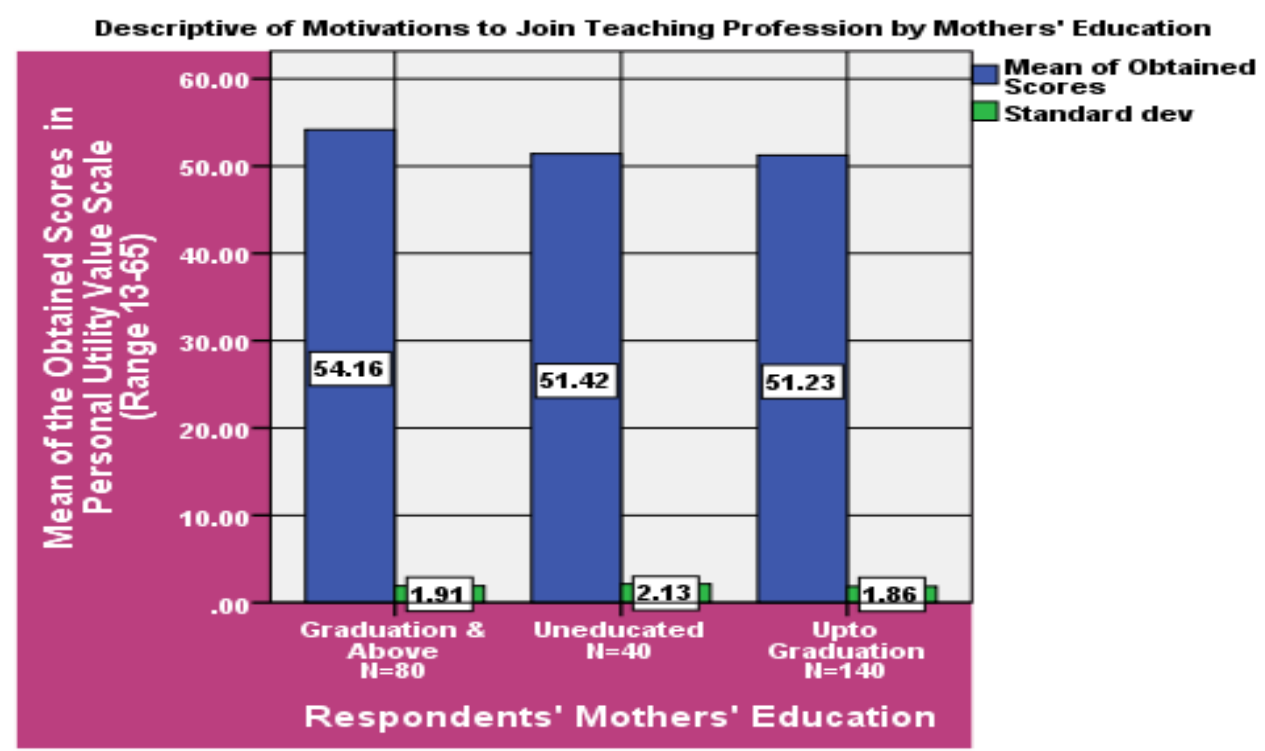

Figure 3: Descriptive of motivations to join teaching profession by mother's education

Figure 3 represents descriptive statistics graphically that the reader may understand the consistency and deviations of the different sub-groups made on the basis of mother education; "uneducated", "up to graduation", and "graduation and above", on the Personal Utility Value Scale. The respondents having educated mothers do not seem to be convinced about teaching as being a lucrative profession. It seems as if the respondents, having uneducated mothers, have less exposure to career choices and resultantly consider teaching profession worthwhile to opt. 


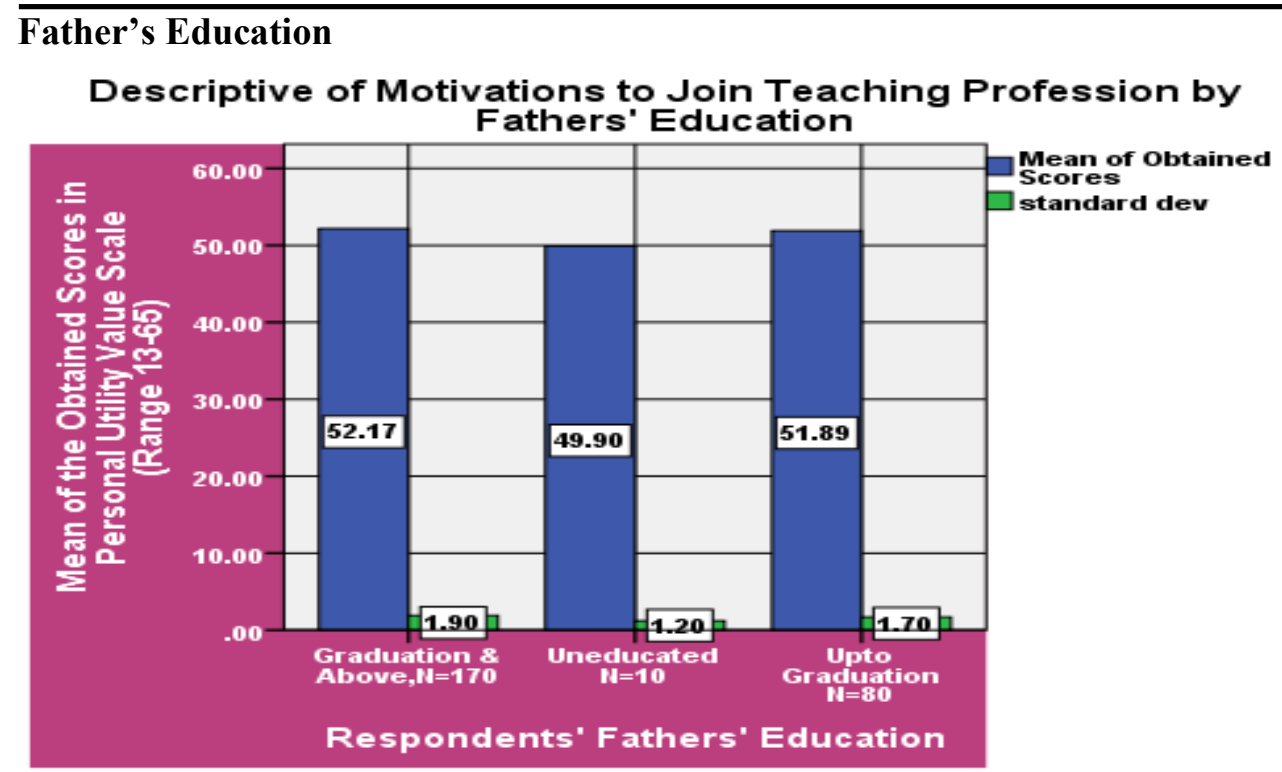

Figure 4: Descriptive of motivations to join teaching profession by father's education

Figure 4 represents descriptive statistics graphically that the reader may understand the consistency and deviations of the different sub-groups made on the basis of father education; "uneducated", "up to graduation", and "graduation and above", on Personal Utility Value Scale,

On the Personal Utility Value Scale the mean of each sub-group found consistent and very close to the population mean, i.e. 49.61. The smaller Standard deviation shows that the difference in their opinions about the Personal Utility Value of the teaching profession is not much greater.

The less educated the parents, the more motivated the teachers

\section{Parents Profession}

Table 5: Difference in motivation of prospective teachers to join teaching profession by parents' profession

\begin{tabular}{|l|l|c|c|c|c|c|c|}
\hline \multicolumn{1}{|c|}{$\begin{array}{c}\text { Type of } \\
\text { Motivation }\end{array}$} & $\begin{array}{c}\text { Parents } \\
\text { Profession }\end{array}$ & N & Mean & SD & t & df & Sig. \\
\hline $\begin{array}{l}\text { Personal } \\
\begin{array}{l}\text { Utility Value } \\
\text { Scale (range } \\
\text { 13-65) }\end{array}\end{array}$ & $\begin{array}{l}\text { Non- } \\
\text { teaching }\end{array}$ & 190 & 52.07 & 1.48 & & & \\
\cline { 2 - 8 } & Teaching & 70 & 49.12 & 2.16 & 2.065 & 258 & .02 \\
\hline
\end{tabular}


In Table 3, researcher presents effect of parents' profession on Prospective teachers' motivation for joining teaching profession, analyzed through t-test statistics explains the results of, Personal Utility Value Scale. In the personal utility value scale, Table 3 shows that respondents having non- teaching parents perceive joining the teaching profession of more importance than those who have teaching parents. 52.07 is the obtained mean of the earlier sub-group on this sub-scale, however 49.12 is the obtained mean of the later subgroup. P-value is .02 which is greater than .05 that shows obtained findings are significant.

Usually it is assumed that children have a tendency to join the same profession as of their parents but results show that parents serving as teachers don't encourage their children to be teachers. The mean score of prospective teachers on motivational belief scale and personal utility value of the children of non-teaching parents is slightly high as compared to teachers children's score. In fact the mean differences show that children of non-teaching parents have slightly better tendencies to be teachers. But the mean score of children of teaching parents on social utility value scale is slightly higher as compared to non-teaching parents children's. The parents, who are in the teaching profession, enjoyed regards and respect from the students. They have a tendency towards a profession to be opted as a career by their children, a socially well recognized profession in social circles.

\section{Previous Achievement}

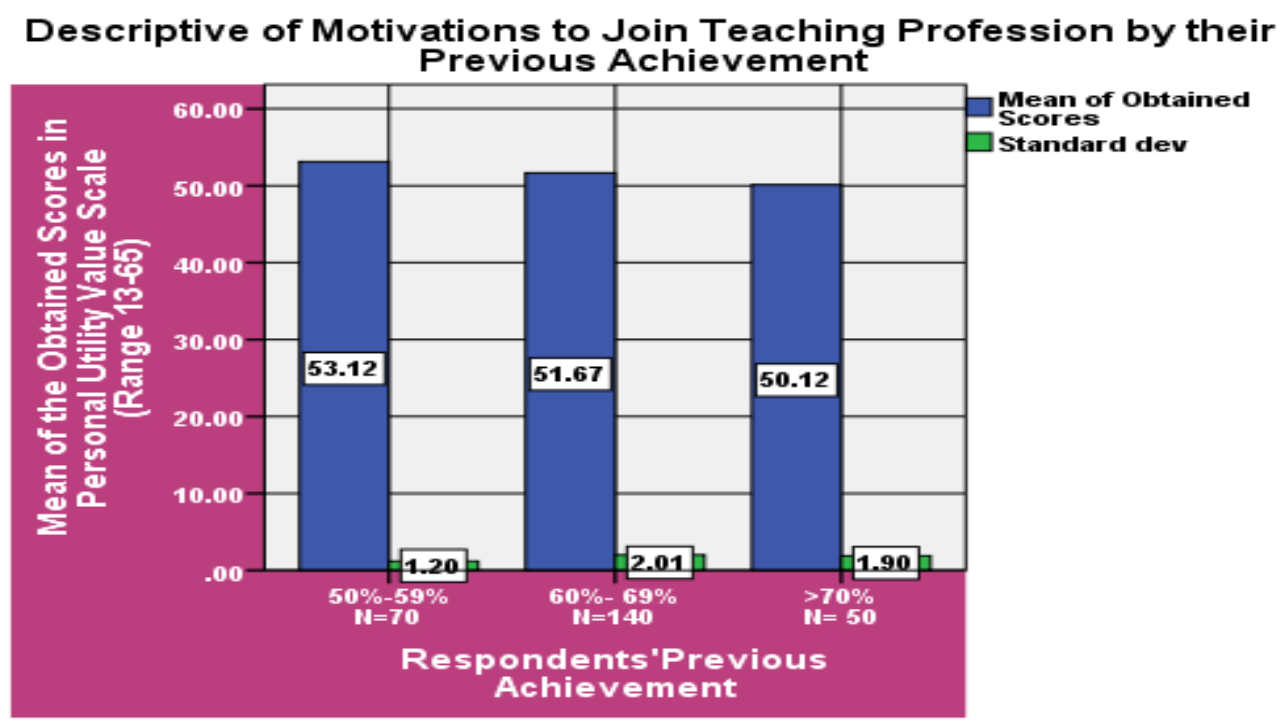

Figure 5: Descriptive of motivations to join teaching profession by student achievement in previous grade 
Figure 5 represents descriptive statistics graphically that the reader may understand the consistency and deviations of the different sub-groups made on the basis of their previous achievement;50-59\% or C grade, $60-69 \%$ or B grade, $70 \%$ above or A-grade on Personal Utility Value Scale. On the Personal Utility Value Scale the mean of each sub-group found consistent and very close to the population mean. The smaller Standard deviation shows that the difference in their opinions about the Personal Utility Value of the teaching profession is not much greater.

According to descriptive statistics the respondent having 60 to 69 or Grade B have above average as compared to $\mathrm{A}$ and $\mathrm{C}$ graders. Moreover, $\mathrm{B}$ grader has more variation as compared to other grades that is $2.01 \mathrm{SD}$.

The data indicates that personal utility scale factors have an important place to join teaching for the low graders as indicated by 53.12 averages as compared to the A \& B grades that is 50.12. Low graders are left with fewer career choices so considering teaching as a last resort, they are more motivated.

High graders have hopes to get admission in other popular programs and can switch over any time. Therefore, they are less motivated.

\section{Decision stage of selecting the teaching profession}

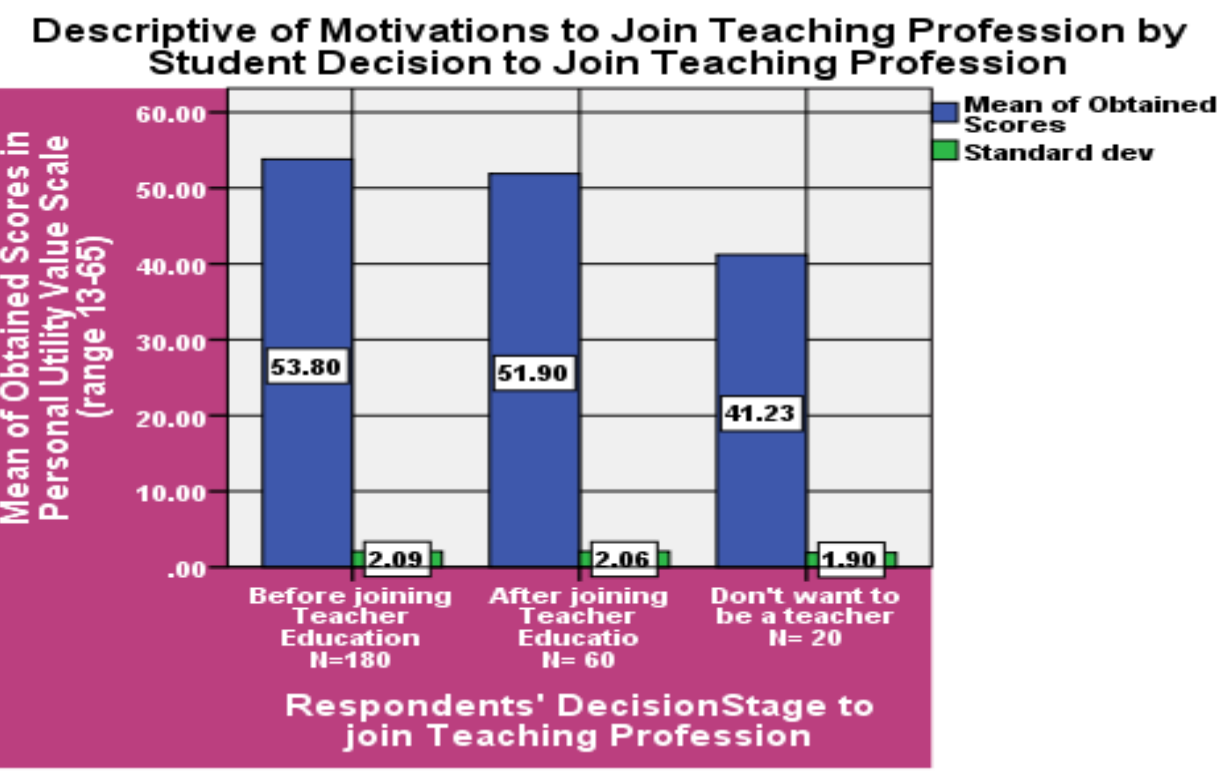

Figure 6: Descriptive of motivations to join teaching profession by student decision to join teaching profession 
Figure 6 represents descriptive statistics graphically that the reader may understand the consistency and deviations of the different sub-groups made on the basis of different stages of their decisions for selecting the teaching profession on Personal Utility Value Scale,

On the Personal Utility Value Scale the mean of each sub-group found consistent and very close to the population mean. The smaller Standard deviation shows that the difference in their opinions about the Personal Utility Value of the teaching profession is not much greater.

Usually it is assumed that those who have decided to become a teacher prior to taking admission in teacher education programs are career oriented and thus more motivated. This data set also shows that those who have decided to become a teacher prior to taking admission in teacher education programs are career oriented and are more satisfied with this program.

\section{DISCUSSION}

The study has generated some interesting findings which challenge the traditionally held myths about factors leading to choice of teaching as profession. The obtained findings presented some interesting facts that demand changes in practicing traditions for motivational factors in choosing teaching as profession.

\section{Fitting Together: Personal vs. Social Value}

Social value of any profession in Pakistan is associated with powers delegated; government employees in other departments with the same service grades enjoy more powers than teachers. Teaching is considered a very ordinary job with no powers to exercise. Consequently, the society did not give them due respect and honor because of lack of authority in the hands of teachers. Ours is a power dominant social system which suppresses the public on the basis of powers delegated to someone.

Teachers' contribution is not realized as professional work thus leading to low social respect as compared to similar professions. It is generally assumed that everyone can teach. Hence teaching profession is not recognized socially as compared to other same level jobs with the same grades. The trend that anyone can teach is misleading and provides misconception towards the teaching profession which is typically a critical task to perform. It results in bludging and counterproductive for motivation stemming through job standards.

\section{Motivated Teachers Come from Semi-urban and Rural Locations}

As indicated by the data, motivated teachers come from semi-urban and rural locations; joining teacher education is generally interpreted as equivalent to becoming school 
teachers by most of the students joining teacher education. This is quite a limited understanding of opportunities related to this profession. Education sector has expanded in the last two decades; varied positions have emerged for teacher education graduates in the public and private sector. Prospective teachers need orientation about these possibilities to motivate them towards teaching profession. The stakeholders and policy makers can flourish campaigns for the purpose which can attract and motivate the prospective teachers having academics and pedagogical skills.

\section{Personal Utility of Teaching for Different Genders}

Since our society is male dominated one, so, it demands males to secure socially lucrative jobs. This aspect is reflected from the data by the notion of less social utility for male teachers. However, males are not attracted to the teaching profession. Females are supposed to be a domestic community by all means. In this sense, if she gets a teaching job, it is of great personal utility for the female individual and her family as well. Resultantly, teaching jobs are most likely to be in the hands of female gender contributing to the motivational factor of having more family time as compared to other professions.

\section{Teaching don't Fascinate Urdu Speaking respondents}

The cosmopolitan cities have diverse career opportunities so the teaching remains a fall back choice. The residents of big cities have better facilities of getting higher education, coaching and training centers to get short courses and in return they get better opportunities for jobs to opt as a carrier. On the other hand, less developed areas have limited resources with lack of educational institutes. They also have fewer career opportunities. The offer of teaching is the most rewarding for everyone in the backward areas of Sindh.

\section{The less educated the parents, the more motivated the teachers}

The prospective teachers having less educated mothers experience the lack of maternal guidance in education and impersonate themselves as teachers who can facilitate the young minds to learn and grow. It is natural phenomena that deprived people put more effort and are intrinsically motivated. The teachers having uneducated mothers are more conscious and show extensive commitment towards their teaching. The growing opportunities and legitimate information to the children can make it possible to motivate them towards teaching jobs.

The prospective teachers having less educated mothers experience the lack of maternal guidance in education and impersonate themselves as teachers who can facilitate the young minds to learn and grow. As revealed by qualitative data gathered through open ended questions, Job security ( 'pakkisarkarinokri'),the flexibility of joining teaching without leaving their hometowns at the start of their career and the transferability factor 
strengthen personal utility value of teaching profession.

\section{Respondents having teaching parents are less motivated than those of having} non-teaching parents in joining teaching profession

The experience of teaching jobs 2-3 decades ago is exclusively different when we compare with today's facilities and opportunities of this job. Improved service structure, self-esteem and social esteem of in -service teachers can convince them to motivate their next generations for joining the teaching profession. Teaching jobs are comparatively improved and in the near future this job will motivate young ones to opt as a career.

The earlier the deciding to become a teacher keeps less satisfied in the program The current program and academic environment does not come up to the career oriented prospective teachers' ideal and preferred specifications of teacher education institutes' academic climate. This may result in high drop-out. Those who have no ideal specification of this program and do not want to be teachers are satisfied.

Teacher education programs are de-motivating prospective teachers, even those joining with high motivation get disappointed on joining. The conception of being a teacher is mismatched with the exposure of teaching and resultantly they left.

\section{RECOMMENDATIONS}

1. Teaching is a profession not an occupation i.e. Teacher-education should develop a teacher professionally by inculcating him or her some specific and relevant skills at higher level, because of them he or she would be recognized as consultant for bring the relevant solutions. This may uplift the social status of teacher in the society 2. Teacher education institutions in small cities need more attention as more motivated teachers can be found in these areas. Awareness of opportunities associated with teacher education need to be advocated more rigorously in teacher education institutions to generate intrinsic and extrinsic motivation among prospective teachers joining this profession.

3. Reforms in the teacher education system focusing on social utility of this profession will make teaching attractive as a career for males also. The results imply that there should be no quota system on gender basis as far as admissions and recruitment policies are concerned.

4. Improvement in service structure can make teaching an attractive option for the respondent living in an urban setting. Improved service structure, self-esteem and social esteem of in-service teachers can convince them to motivate their next generations to join the teaching profession for personal utility value.

5. The administration should devise teacher education as per demands of the 
locality as the people who have Sindhi and other regional languages as their first language are already motivated to join teaching. To conserve this motivation the policy makers should address the provision of teacher education opportunities in their local settings as they solely rely on the job security factor of motivation.

6. Educational Campaign coupled with improved service structure may convince Graduate parents that ADE/ B.Ed are professional degrees with career growth. There should be parental guidance campaigns for focusing careers in education.

7. For low achievers admitted in ADE/ B.Ed (Hons.), teacher education programs should devise strategies to enhance their motivation for retention in teaching.

8. Teacher licensing on the pattern of medical and engineering professions may be initiated to ensure the retention of high achievers in teaching. It may help avoiding the bludging factor resulting in low productivity and lack of responsibility.

9. Teacher-Education Department should bring improvements in its academic environment that may motivate the career oriented prospective teachers to be retained in the department

\section{REFERENCES}

Bruinsma, M. \& Jansen, E. P. W. A. (2010). Is the motivation to become a teacher related to pre-service teachers' intentions to remain in the profession? European Journal of Teacher Education, 33(2), 185-200.

Cameron, J., \& Pierce, W. D. (2002).Rewards and intrinsic motivation: Resolving the controversy. Westport, Conn: Bergin \& Garvey. - See more at: http://aubreydaniels.com/blog/category/creativity/\#sthash.9M5GvR9f.dpuf

DuBrin, A. (2008). Essentials of Management, 8/E, South-Western.

Edmonds, S., Sharp, C. \&Benefield, P. (2002).Recruitment to and Retention in Initial Teacher

Fazal-ur-Rehman (2005).Nocturnal Enuresis.Pakistan Armed Forces Medical Journal, 4 (Dec.) retrieved from http://www.pafmj.org/showdetails.php? id=12\&t=r

Glynn, S.M., L.P. Aultman, \& A.M. Owens.(2005). Motivation to Learn in General Education Programs.The Journal of General Education 54(2): 150-170.

Malloy, C. L., \&Wohlstetter, P. (2003). Working conditions in charter schools: What's the appeal for teachers? Education and Urban Society, 35(2), 219-241.

McInerney, D. M., Maehr, M. L., \& Dowson, M. (2004). Cross-cultural studies of motivation and achievement: Implications for applied settings. In C. D Spielberger (Ed.), Encyclopedia of applied psychology.Academic Press.

Schutz, P. A., Crowder, K. C., \& White, V. E. (2001).The development of a goal to become a teacher.Journal of Educational Psychology, 93(2), 299-308.

Sinclair, C. (2008). Initial and changing student teacher motivation and commitment to teaching.Asia-Pacific Journal of Teacher Education, 36 (2), 79-104.

ÜSTÜNER, M., DEMIRTAŞ, H. \& CÖMERT, M. (2009). The Attitudes of Prospective Teachers Towards the Profession of Teaching (The Case of Inonu University, Faculty of Education). Education and Science, 34(151), 140-155. 
Watt, H. M. G. \& Richardson, P. W. (2007). Motivational factors influencing teaching as a career choice: Development and validation of the FIT-Choice Scale. Journal of Experimental Education, 75(3), 167-202.

Williams, K. C., \& Williams, C. C. (2011).Five key ingredients for improving student motivation. Research in Higher Education Journal, 12(August). Retrieved from http://www.aabri.comwww.aabri.com/manuscripts/11834.pdf 